\title{
Pemanfaatan Tanaman Herbal Sebagai Antibiotik Alami Untuk Meningkatkan Indeks Performa (Ip) Ayam Broiler
}

\author{
Muhammad Saleh ${ }^{1, a}$, Octovianus SR Pasanda ${ }^{1, b}$ \\ ${ }^{1}$ Teknik Kimia, Politeknik Negeri Ujung Pandang, Jl. Perintis Kemerdekaan Km 10, Makassar, 90245, Indonesia \\ a muhsaleh645@gmail.com \\ bo.pasanda@yahoo.com
}

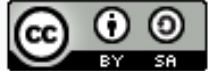

Abstract--The research was aimed to determine the volume and time of giving the natural antibiotic which are optimal for the value of Index Performance (IP) of broiler chickens. The first treatment variable was: giving natural antibiotics with a dose for partition $10.05 \mathrm{~mL} / 40 \mathrm{~mL}$ water / chicken / day, partition 2 $0.1 \mathrm{~mL} / 40 \mathrm{~mL}$ water / chicken / day, partition $30.15 \mathrm{~mL} / 40 \mathrm{~mL}$ water / chicken / day, partition 4 (synthetic antibiotics as a comparison) and carried out for 35 days in a fixed time of 24 hours. Optimal results with the best Index Performance (IP) obtained from the first variable followed by the second treatment variable, the time of giving natural antibiotics for partition 1 given once a day, partition 2 every two days, and partition 3 three days with a constant giving dose $0.15 \mathrm{~mL} / 40 \mathrm{~mL}$ water / chicken / day for 35 days. The parameters observed were: (1) average body weight, (2) weight gain, (3) feed consumption, (4) feed conversion, and (5) number of live chickens. From these data the IP of broiler chickens was calculated and from the two variables obtained the optimal dose and time of giving natural antibiotics. Based on research results from the product, the best of giving natural antibiotic volume is $0.15 \mathrm{~mL} /$ chicken or equal to $4.2 \mathrm{~mL} / 28$ chickens which it is able to increase the value of broiler chicken IP until harvest time. From the optimal results obtained in the trial volume variation of giving natural antibiotic, the experiment can be continued with the aim of determining the optimal time of giving herbal antibiotics namely the best results are obtained once a day for 28 chickens because it shows that the giving natural antibiotic is able to increase the IP value of broiler chickens until harvest.

Keywords--broiler chicken, performance index, natural antibiotics

\footnotetext{
Abstrak--Penelitian ini bertujuan menentukan volume dan waktu pemberian antibiotik alami yang optimal terhadap nilai Indeks Performa (IP) ayam broiler. Variabel perlakuan ke-1 yaitu: pemberian antibiotik alami dengan dosis untuk sekat 1 $0.05 \mathrm{~mL} / 40 \mathrm{~mL}$ air/ekor/hari, sekat $20.1 \mathrm{~mL} / 40 \mathrm{~mL}$ air/ekor/hari, sekat $30.15 \mathrm{~mL} / 40 \mathrm{~mL}$ air/ekor/hari, sekat 4 (pemberian antibiotik sintetik sebagai pembanding) dan dilakukan selama 35 hari dalam waktu pemberian yang tetap yaitu 24 jam. Hasil optimal dengan Indeks Performa (IP) terbaik yang di peroleh dari variabel ke-1 dilanjutkan variabel perlakuan ke-2 yaitu waktu pemberian antibiotik alami untuk sekat 1 diberikan sehari sekali, sekat 2 dua hari sekali, dan
}

sekat 3 tiga hari sekali dengan dosis pemberian yang tetap yaitu $0.15 \mathrm{~mL} / 40 \mathrm{~mL}$ air/ekor/hari dilakukan selama 35 hari. Adapun parameter yang diamati adalah: (1) berat badan rata-rata, (2) pertambahan berat badan, (3) konsumsi pakan, (4) konversi pakan, dan (5) jumlah ayam hidup. Dari data tersebut dihitung IP ayam broiler dan dari kedua variable tersebut dipeoleh dosis dan waktu pemberian antibiotik alami optimal. Berdasarkan hasil penelitian dari produk dihasilkan volume pemberian antibiotik alami terbaik yakni pada pemberian $0.15 \mathrm{~mL} / \mathrm{ekor}$ atau setara dengan $4.2 \mathrm{~mL} / 28$ ekor dimana pada pemberiannya mampu meningkatkan nilai IP ayam broiler hingga masa panen. Dari hasil optimal yang diperoleh pada percobaan variasi volume pemberian antibiotik alami, percobaan dapat dilanjutkan dengan tujuan menentukan waktu optimal pemberian antibiotik herbal yakni diperoleh hasil terbaik pada pemberian sehari sekali untuk 28ekor karena menunjukkan bahwa pemberiannya mampu meningkatkan nilai IP ayam broiler hingga masa panen.

Kata kunci-- ayam broiler, indeks performa, antibiotik alami

\section{Pendahuluan}

Ayam broiler merupakan ternak unggas yang dimanfaatkan sebagai sumber protein hewani bagi masyarakat. Ayam broiler tumbuh cepat dalam waktu singkat \pm umur 45 hari dapat dipanen [1]. Pemeliharaan ayam broiler dilakukan secara intensif karena mempunyai daya tahan tubuh yang rentan terhadap lingkungan sehingga memiliki resiko kematian tinggi [2]. Adapun upaya penanggulangan sensitifitas ayam broiler terhadap lingkungan dapat dilakukan dengan pemberian antibiotik sintetik terutama pada daerah tropis seperti di Indonesia, namun penggunaan antibiotik sintetik sudah tidak dikehendaki karena diketahui pemberiannya meninggalkan residu pada daging, sehingga tidak aman bagi konsumen [3]. 
Salah satu alternatif yang bisa dilakukan agar konsumen aman dari residu antibiotik sintetik yaitu dengan penggunaan antibiotik alami [4] dan dari tanaman herbal, penggunaan duabelas macam ramuan herbal (temulawak, jahe, sirih, kunyit, bawang putih, kemangi, sereh, bawang merah, kencur, lengkuas, temu hitam dan temu kunci) yang difermentasi dan cairan hasil fermentasi dengan dosis $2,5 \mathrm{~mL} / \mathrm{L}$ setiap 25 ekor ayam arab merupakan dosis yang aman ditinjau dari kandungan kolesterol, trigliserida sarta gambaran histopatologi organ dan indeks performa yang sangat baik [5]. Dari duabelas bahan ramuan herbal terdapat beberapa bahan yang memiliki kandungan zat bioaktif yang sama sehingga perlu mengurangi jenis bahan menjadi tujuh tanaman ramuan herbal (temulawak, jahe, sirih, kunyit, bawang putih, kemangi dan sereh) dan pengaturan pemberian ramuan herbal yaitu setiap hari menjadi dua hari sekali [6].

Berdasarkan hal-hal tersebut, maka dilakukan penelitian untuk mengkaji penggunaan tujuh bahan ramuan herbal yang bertujuan untuk meningkatkan Indeks Performa (IP) ayam broiler dan sekaligus sebagai alternatif pengganti antibiotik sintetik.

Pada penelitian ini dibuat antibiotik alami dengan menggunakan tujuh bahan ramuan herbal (temulawak, jahe, sirih, kunyit, bawang putih, kemangi, dan sereh) kemudian dicampur dan ditembahkan molase lalu difermentasi selama 14 hari dengan menggunakan EM4 khusus untuk ternak, lalu diujikan langsung ke ayam broiler.

\section{Metode Penelitian}

\section{A. Waktu dan Tempat Penelitian}

Penelitian dilaksanakan pada bulan Februari sampai dengan April 2019 di Desa Moncongloe Kabupaten Maros.

\section{B. Alat dan Bahan}

Alat yang digunakan: wadah fermentasi (gallon air 25L), ember, timbangan digital, pisau, blender, kain saring, pengaduk kayu, gayung, botol plastik, wadah pakan, wadah air minum, lampu pijar 10 watt ( 8 buah), gelas ukur $(100 \mathrm{~mL})$, gelas kimia $(500 \mathrm{~mL}$ dan $1000 \mathrm{~mL})$, pipet ukur $(5 \mathrm{~mL}$ dan $25 \mathrm{~mL})$, kain lap, terpal, kandang ayam (ukuran 5 x $10 \mathrm{~m}$ ).

Bahan yang digunakan: temulawak, jahe, daun sirih, kunyit, bawang putih, daun kemangi, batang sereh, molase, EM-4 (Effective Microorganisme), air bersih, bibit ayam broiler (DOC), pakan BR-1 (pakan ayam broiler untuk umur 0-21 hari) dan BR-2 (pakan ayam broiler untuk umur 21-35 hari), antibiotik sintetik vita chicks.

\section{Tahapan Penelitian}

\section{Persiapan kandang}

Sebelum penelitian dilaksanakan hal utama yang harus dipersiapkan yaitu mempersiapkan kandang terlebih dahulu. Hal yang dilakukan dalam mempersiapkan kandang diantaranya sanitasi kandang dan peralatan kandang. Kandang yang digunakan pada penelitian ini berbentuk kandang panggung dengan tinggi pijakan dari tanah $1.5 \mathrm{~m}$ kemudian disekat dengan ukuran masing-masing $1 \times 1.5 \mathrm{~m}$ (untuk umur 1-14 hari) dan $3 \times 3 \mathrm{~m}$ (untuk umur 15-35 hari) sebanyak 4 sekat dan dilengkapi dengan tempat makan, tempat minum, lampu 10 watt, serta alasnya diberi sekam. Pada sisi sekeliling kandang ditutup dengan terpal pada saat periode starter (DOC) agar kandang dalam kondisi hangat.

\section{Pembuatan antibiotik alami}

Bahan-bahan berupa temulawak, jahe, kunyit, bawang putih, batang sereh dikupas lalu ditimbang masing-masing $\pm 37,5 \mathrm{~g}$. Kemudian dicuci bersih dan dipotong kecil-kecil $( \pm 1 \mathrm{~cm})$, dihaluskan bersamaan dengan daun kemangi dan daun sirih yang telah ditimbang masing-masing $\pm 37,5 \mathrm{~g}$ dengan ditambahkan air bersih $100 \mathrm{~mL}$. Setelah semua bahan sudah halus, selanjutnya dimasukkan dalam wadah fermentasi.

Ke dalam wadah fermentasi ditambah $12 \mathrm{~mL}$ EM-4 untuk ternak, $15 \mathrm{~mL}$ molase dan ditambahkan air bersih sebanyak 2.9L, diamkan selama 5 menit. Setelah 5 menit, kemudian diaduk sampai rata. Ramuan tersebut difermentasi dalam keadaan tertutup. Fermentasi dilakukan selama 14 hari. Sekali sehari ramuan dihomogenkan dengan cara digoyangkan selama 5 menit. Setelah 14 hari, ramuan disaring dan cairan yang diperoleh dimasukkan ke dalam botol-botol plastik dan disimpan dalam ruang pendingin agar tidak mudah rusak.

\section{Pemberian antibiotik alami dan antibiotik sintetik}

Ada dua variabel perlakuan antibiotik alami pada ayam broiler:

(1) Variabel dosis (volume) pemberian antibiotik alami Kandang disekat menjadi empat sekat, masingmasing sekat berisi 28 ekor ayam broiler.

- Sekat 1 diberikan antibiotik alami sebanyak 0.05 $\mathrm{mL} / 40 \mathrm{~mL}$ air/ekor/hari.

- Sekat 2 diberikan antibiotik alami sebanyak 0.1 $\mathrm{mL} / 40 \mathrm{~mL}$ air/ekor/hari. 
- Sekat 3 diberikan antibiotik alami sebanyak 0.15 $\mathrm{mL} / 40 \mathrm{~mL}$ air/ekor/hari.

- Sekat 4 kontrol menggunakan antibiotik sintetik Vita chicks (cara pemberiannya sesuai prosedur yang dilakukan oleh peternak ayam broiler).

Dilakukan penimbangan berat badan dan pakan untuk semua sekat sehari sekali selama 35 hari dalam waktu 24 jam. Hasil optimal dengan Indeks Performa (IP) terbaik yang di peroleh dari variabel perlakuan ke1digunakan untuk dilanjutkan pada variabel perlakuan ke-2.

(2) Variabel perlakuan waktu pemberian antibiotik alami Waktu pemberian antibiotik alami, dilakukan

berbeda masing-masing sekat selama 35 hari:

- Sekat 1 ayam broiler diberi antibiotik alami sehari sekali.

- Sekat 2 ayam broiler diberi antibiotik alami setiap dua hari sekali.

- Sekat 3 ayam broiler diberi antibiotik alami setiap tiga hari sekali.

- Sekat 4 dikosongkan.

Dilakukan penimbangan berat badan dan pakan untuk semua sekat sehari sekali selama 35 hari dalam waktu 24 jam, dan hasil optimal dengan nilai Indeks Performa (IP) terbaik dapat ditentukan sebagai waktu optimal pemberian antibiotik alami.

4. Parameter yang diamati

Adapun parameter-parameter yang diamati: (1) berat badan rata-rata, (2) pertambahan berat badan, (3) konsumsi pakan, (4) konversi pakan, (5) jumlah ayam hidup dan (6) Indeks Performa (IP) ayam broiler.

\section{Hasil dan Pembahasan}

Variasi perlakuan tahap pertama yaitu variasi volume pemberian antibiotik alami dan antibiotik vita chicks yang dijadikan sebagai pembanding. Variasi volume ini bertujuan untuk mengetahi pengaruhnya terhadap IP ayam broiler, untuk memperoleh IP data yang diperlukan adalah berat badan rata-rata jumlah ayam yang hidup \% dan konversi pakan dari keseluruhan lampiran tersebut hasil akhir perolehan nilai IP dapat dilihat pada lampiran. Adapun nilai IP yang diperoleh dapat dilihat pada tabel 1.

Tabel 1. Pengaruh Variasi Volume Pemberian Antibiotik Alami Terhadap Indeks Performa (IP)

\begin{tabular}{ccccc}
\hline \multirow{2}{*}{ Umur (hari) } & \multicolumn{4}{c}{$\begin{array}{c}\text { Indeks Performa } \\
(\mathrm{kg} / 5 \text { hari })\end{array}$} \\
\cline { 2 - 5 } & $0.05 \mathrm{~mL}$ & $0.1 \mathrm{~mL}$ & $0.15 \mathrm{~mL}$ & sintetik \\
\hline \multirow{2}{*}{5} & 236.84 & 266.21 & 271.16 & 285.97
\end{tabular}

\begin{tabular}{rrrrr}
10 & 578.24 & 555.62 & 558.70 & 545.75 \\
15 & 725.07 & 757.71 & 767.11 & 679.36 \\
20 & 789.78 & 849.18 & 860.99 & 814.14 \\
25 & 742.75 & 873.35 & 963.49 & 1017.18 \\
30 & 398.25 & 458.19 & 1037.53 & 1061.44 \\
35 & 383.47 & 447.28 & 1089.79 & 1166.34 \\
\hline
\end{tabular}

Bedasarkan data hasil penelitian pada tabel 1 dapat dibuat grafik pengaruh pemberian antibiotik alami terhadap nilai IP pada ayam broiler. Hasilnya dapat dilihat pada gambar 1.

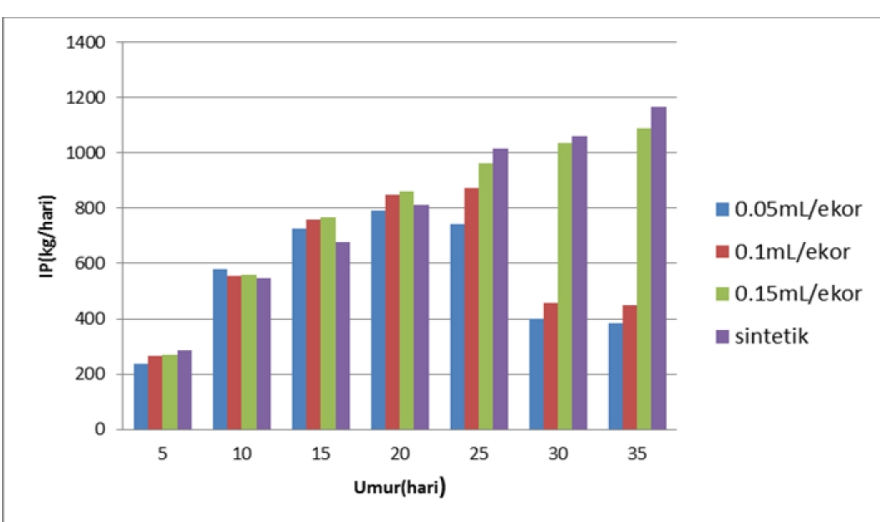

Gambar 1. Grafik Pengaruh Variasi Volume Pemberian Antibiotik Terhadap Indeks Performa

Terlihat pada gambar 1 bahwa pada pemberian antibiotik alami volume $4.2 \mathrm{~mL} / 28$ ekor atau setara dengan $0.15 \mathrm{~mL} /$ ekor mampu meningkatkan nilai IP ayam broiler dari umur 5 sampai 35 hari. Tetapi hal itu berbeda pada volume pemberian antibiotik alami $1.4 \mathrm{~mL} / 28$ ekor atau setara dengan $0.05 \mathrm{~mL} / \mathrm{ekor}$ menunjukkan bahwa pada volume pemberian tersebut hanya mampu meningkatkan nilai IP ayam broiler hingga masa penggunaan 20 hari, kemudian mengalami penurunan pada penggunaan 25 hari keatas. Hal serupa ditunjukkan pada volume pemberian antibiotik alami $0.1 \mathrm{~mL} /$ ekor atau setara dengan $2.8 \mathrm{~mL} / 28$ ekor.

Penurunan nilai IP ayam broiler tersebut terjadi karena kurangnya dosis antibiotik yang diberikan. Dengan berkurangnya dosis pemberian maka jumlah kadar senyawa yang berfungsi sebagai anti virus dan anti fungi akan berkurang sehingga kekebalan tubuh yang dimiliki ayam broiler menurunn, penyakit mudah menyerang dan menyebabkan kematian.

Variasi perlakuan tahap kedua yaitu variasi waktu pemberian antibiotik alami. Variasi waktu ini bertujuan untuk mengetahi pengaruhnya terhadap IP ayam broiler, untuk memperoleh IP data yang diperlukan sama seperti 
pada perlakuan pertama. Adapun nilai IP yang diperoleh dapat dilihat pada tabel 2 .

Tabel 2. Pengaruh Variasi Waktu Pemberian Antibiotik Alami Terhadap Indeks Performa (IP)

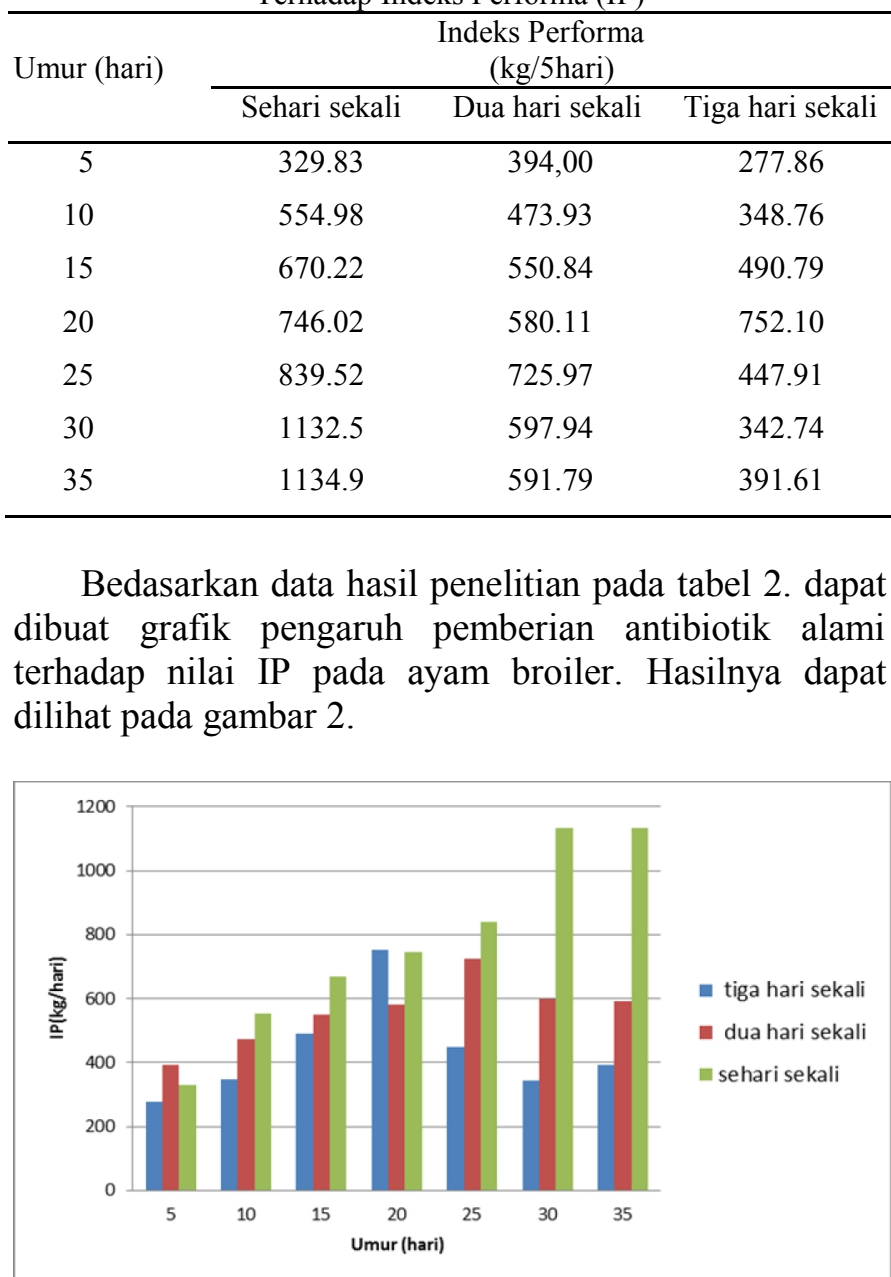

Gambar 2. Pengaruh Variasi Waktu Pemberian Antibiotik Terhadap Indeks Performa

Terlihat pada gambar 2 pada waktu pemberian antibiotik alami sehari sekali untuk 28ekor mampu meningkatkan nilai IP ayam broiler dari umur 5 sampai 35 hari. Tetapi berbeda pada waktu pemberian antibiotik alami dua hari sekali untuk 28ekor menunjukkan bahwa pemberiannya mampu meningkatkan nilai IP ayam broiler hingga masa penggunaan 25 hari, kemudian mengalami penurunan pada penggunaan 30 hari keatas. Perberbeda tersebut juga ditunjukkan pada waktu pemberian tiga hari sekali untuk 28ekor bahwa pemberiannya mampu meningkatkan nilai IP ayam broiler hingga masa penggunaan 20 hari, kemudian mengalami penurunan pada penggunaan 25 hari keatas.
Penurunan nilai IP ayam broiler tersebut terjadi karena rentan waktu pemberian antibiotik yang jauh. Dengan adanya rentan waktu pemberian tersebut maka dosis yang diterima ayam broiler akan berkurang sehingga membuat kekebalan tubuh yang dimiliki ayam broiler menurun, penyakit mudah menyerang dan menyebabkan kematian.

Menurunt wiedosari E dan Wahyuwandani S tahun 2015, bahwa ayam broiler memiliki tubuh yang rentan terhadap penyakit pada usia 11-30 hari, sehingga apabila pada usia starter pemberian antibiotik tidak terpenuhi maka penyakit akan mudah masuk dan bersarang didalam tubuh ayam broiler sehingga dapat menimbulkan kematian.

\section{Kesimpulan}

Berdasarkan hasil pembahasan penelitian ini, maka dapat disimpulkan bahwa:

1. Volume pemberian antibiotik alami yang optimal adalah $0.15 \mathrm{~mL} / \mathrm{ekor}$ atau serata dengan $4.2 \mathrm{~mL} / 28$ ekor dengan Indeks Performa 1089.87 selama 35 hari.

2. Waktu pemberian antibiotik yang optimal adalah sehari sekali dengan Indeks Performa 1134.89 selama 35 hari.

Saran

1. Perlu dilakukan penelitian lanjut untuk meningkatkan konsentrasi dosis antibiotik alami hingga ditemukan dosis yang sesuai dengan penggunaan antibiotik sintetik .

2. Perlu dilakukan analisa uji coba terhadap bakteri penyebab penyakit terhadapayam broiler..

\section{Ucapan Terima Kasih}

Ucapan terima kasih kami sampaikan kepada Politeknik Negeri Ujung Pandang yang banyak memberikan kontribusi positif serta membiayai penelitian ini.

\section{Daftar Pustaka}

[1] Masni, Arif . I., dan Maria.B.2010. Pengaruh penambahan kunyit (curcuma domestica val) atauTemulawak (curcuma xanthorrhiza roxb) dalam air minum Terhadap persentase dan kualitas organoleptik karkas Ayam broiler. 6(1):8

[2] Etikaningrum dan Irwantoro, S. 2017. "Kajian residu antibiotika pada produk ternak unggas di Indonesia". Jurnal Ilmu Produksi dan Teknologi Hasil Peternakan: 29-33

[3] Agustina, L. 2012. "Penggunaan ramuan herbal sebagai feed additive untuk meningkatkan performans ayam arab". Prosiding Lokakarya Nasional Teknologi dalam Mendukung Usaha ternak Unggas Berdayasaing. Hal: 47-52. 
[4] Agustina, L dkk. 2017. "Ramuan herbal dan desinfektan alami pada ayam di Kabupaten Bantaeng”. Seminar Nasional Peternakan 3. Hal: 350-355

[5] Rahmah.A, Suthama. N, Dan Yunianto. V.D.2013. total bakteri asam laktat dan escherichia coli pada ayam broiler yang diberi campuran herbal dalam ramsum. animal agriculture journal.2(3):40.

[6] Mahendra.2005.13 Jenis Tanaman Obat Ampuh.Cetakan 1. Penebar Swadaya. Jakarta. 